\title{
Development and characterization of monospecific anti-Sgt1 antibodies
}

\author{
Kapustian L.N., Rozhko O.T., Bobyk V.I., Kroupskaya I.V., Sidorik L.L.
}

Institute of molecular biology and genetics NAS of Ukraine

Academicain Zabolotnog str., 150, Kyiv, 03680 Ukraine

1.m.kapustian@imbg.org.ua

\begin{abstract}
The method of development and purification of monospecific polyclonal antibodies against Sgt1 was described and their characteristics were presented. Protein Sgt1 plays an important role in the regulation of cell cycle, Hsp90-related proteasome degradation of proteins and pro/anti-apoptotic signaling along with other molecular chaperons and co-chaperons. The further investigation of Sgt1 role and its functioning with other members of Hsp90-chaperons family is important for elucidation of the cell signaling regulation, which is significant for cardio-vascular pathologies progression, particularly, for dilated cardiomyopathy.
\end{abstract}

Keywords: monospecific antibodies, Sgt1, chaperons

Introduction. The study of the mechanisms of anti-stress response is quite important for evaluation of cardio-vascular pathologies progression and for development of new effective therapeutic tools based on the apoptotic signaling blockage. Specialized family of anti-stress proteins including molecular chaperons, their co-chaperons, and target proteins plays a critical role in pro- and anti-apoptotic signaling. Recently discovered protein Sgt1 is a potential co-chaperon and/or target protein.

Sgt1 has been first described in regulation of cell circle in yeast [1] which suppresses G2 allele of Skp1 protein, one of the kinetochore CBF3 core complex [2]. Recently it has been shown that Sgt1 plays a role in Hsp90-related proteasome degradation of proteins via

(C) KAPUSTIAN L.N., ROZHKO O.T., BOBYK V.I., KROUPSKAYA I.V., SIDORIK L.L., 2007 interaction with complex of Skp1-Cul1-F-box (SCF) E3 ubiquitin-ligase [3]. Sgt1 expression has been observed in numerous eukaryotes including plants and mammals [4, 5]. However, mammalian Sgt1 cellular distribution and peculiarities are poorly understood. The investigation on Sgt1 expression in human tissues revealed the variation of its expression in different tissues with maximum level in brain, kidney, lung, intestines, and heart [6]. The sequence-analysis of Sgt1-proteins purified from yeast, human cells, rat, rice, and Arabidopsis suggests 3 conservative domains (tetratricopeptide repeat (TPR), CHORD-containing proteins and Sgt1 (CS), and Sgt1-specific domain (SGS), as well as two variable regions - VR1 and VR2 $[7,8]$. TPR is known as HSP-binding domain, SGS-domain interacts with $\mathrm{Ca}^{2+}$-binding proteins of $\mathrm{S} 100$-family [9], and CS-domain has a high sequence-homology with Hsp90-co-chaperon p23 protein [10]. 
The study on the role and function of Sgt1 in complexes with other members of Hsp90 family is important for elucidation of the cell signaling regulation, which is sufficient for cardio-vascular pathologies progression, in particular, for dilated cardiomyopathy. The development of monospecific antibodies with high affinity is necessary for this purpose although it could be difficult due to high conservation of Sgt1 molecule structure which determines its low immunogenicity.

Materials and methods. Recombinant human Sgt1 of $95 \%$ purity (truncated C-end domain, molecular weight $20 \mathrm{kDa}$ ) is a kind gift of Prof. Anna Filipek (Nencki Institute of Experimental Biology of Polish Academy of Sciences, Warsaw, Poland). Hsp90 preparation purified from bovine brain is a kind gift of Prof. Jacek Kuznicki (International Institute of Cell and Molecular Biology, Warsaw, Poland). Recombinant GroEL was purified according to [24].

Animal experiments have been carried out in accordance to the Ukrainian Ethic Committee Protocol. Animals were decapitated under ester narcosis, and the heart was stopped by perfusion with cold phosphate buffer saline (PBS).

Total lysate and cytoplasmic postmitochondrial fractions of cardiomyocytes were obtained as described earlier in [11]. Heart section was homogenized in RIPA buffer (25 mM Tris/HCl, pH 7.5; 2 mM EDTA; 5 mM $\mathrm{MgCl}_{2} ; 250 \mathrm{mM}$ sucrose , $0.1 \% \mathrm{NP}-40,0.1 \%$ DTT, $0.1 \%$ protease nuclear inhibitor cocktail (Sigma, USA). Total lysate was obtained after centrifugation at $4000 \mathrm{~g}$, $15 \mathrm{~min}$, and postmitochondrial cytoplasmic fraction after centrifugation at $10000 \mathrm{~g}, 40 \mathrm{~min}$.

Protein purity was checked by electrophoresis in $12 \%$ PAGE at denaturing conditions by the method of Laemmli [12].

Protein concentrations were estimated by the Bradford's method [13].

Preparation of anti-Sgt1 monospecific polyclonal antibodies. The immunization of rabbits has been performed according to the specific scheme developed in our laboratory recently [14]. In 7 days after the last immunization, the blood from rabbits was collected, the serum was tested for content of anti-Sgt1 antibodies using ELISA method. Immunoglobulins were precipitated from the serum with sodium sulphate buffer at $50 \%$ saturation.
Immunoglobulins were stored under saturated sodium sulphate buffer with $0.3 \% \mathrm{NaN}_{3}$ before purification at $4^{\circ} \mathrm{C}$.

Purification of antibodies using DEAE-Toyopearl 650M column chromatography. DEAE-Toyopearl650M column (ToyoSoda, Japan) was equilibrated with phosphate buffer saline (PBS), $\mathrm{pH}$ 7.2. Precipitate of immunoglobulins was dissolved in PBS buffer with 0.1 mM PMSF, loaded onto column (40-50 mg of total proteins per $2.5 \mathrm{ml}$ of resin), and washed by $2-3$ volumes of PBS. Unbounded fractions were collected, and further purification of antibodies was conducted using Protein G-Sepharose column (Pharmacia, Sweden), equilibrated with PBS buffer. Purified on DEAE-Toyopearl immunoglobulins were applied on the column $(1.5 \mathrm{mg}$ of protein per $1 \mathrm{ml}$ of resin) and incubated for 2-3 hours at room temperature. The column was washed by PBS buffer, elution of Ig was done with $0.2 \mathrm{M}$ glycine buffer ( $\mathrm{pH} 2.5$ ) with neutralization of eluate by Tris base. The purity of IgG obtained was controlled by SDS-PAGE electrophoresis. IgG-containing fractions were dialyzed against PBS-buffer per night at $4^{\circ} \mathrm{C}$, saturated by glycerol up to $50 \%$ and stored at $-20^{\circ} \mathrm{C}$.

Affine column synthesis. Affine column was prepared by coupling highly purified antigen (truncated C-end domain of Sgt1) to the CNBr-activated Sepharose 4B (Pharmacia, Sweden) as described in [14].

Affine purification of specific antibodies. IgG, purified by the Protein G-Sepharose chromatography, were dialyzed over night with PBS buffer, $\mathrm{pH} 7.4$ at $+4^{\circ} \mathrm{C}$, and applied to the column (10-12 $\mathrm{mg}$ per $2 \mathrm{ml}$ of resin) with subsequent incubation at room temperature for 3-4 hours. After washing with $\mathrm{PBS} / 0.5 \mathrm{M} \mathrm{NaCl}$ buffer, $\mathrm{pH} 7.4$, and then with PBS, coupled antibodies were eluted by $0.2 \mathrm{M}$ glycine buffer, $\mathrm{pH} 2.5$ with neutralization by $1 \mathrm{M}$ Tris-base, $\mathrm{pH}$ 11.0. Combined protein fractions were dialyzed over night in PBS buffer with PMSF, $\mathrm{pH} 7.4$ at $+4^{\circ} \mathrm{C}$.

The concentration of antibodies obtained was assayed spectrophotometrically using the extinction coefficient at $280 \mathrm{~nm} \mathrm{E}=1.35 \mathrm{~cm}^{-1} \mathrm{mg}^{-1} \mathrm{ml}$ and $\mathrm{M}_{\mathrm{r}} 150000$.

The specificity of antibodies obtained at each purification step was controlled by the ELISA method and their purity was estimated by $12 \%$ PAGE-SDS electrophoresis. 


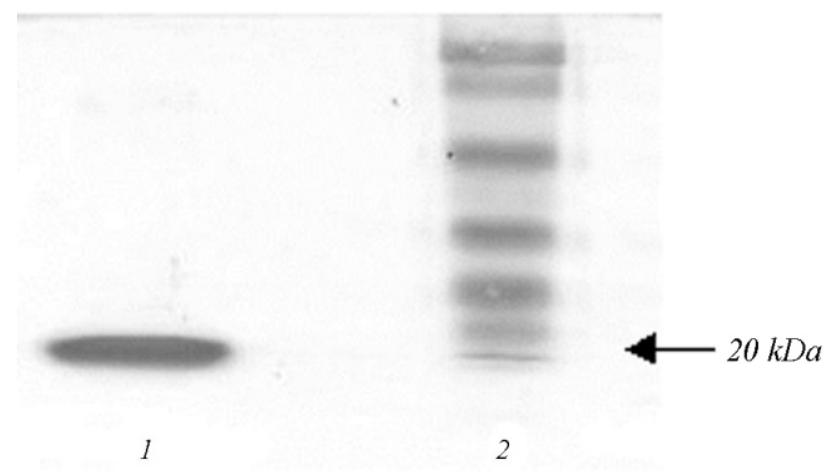

Fig.1 Electrophoretic analysis of the purity of human recombinant Sgt1 ( $\Delta \mathrm{C}$ fragment), used as antigen for immunization of rabbits: 1 - human recombinant $\mathrm{Sgt1}$ ( $\Delta \mathrm{C}$ fragment); 2 - mixture of standard protein markers (Sigma)

Enzyme-linked immunosorbent assay(ELISA). ELISA assay was performed as described in [15] with modifications. Antigen (recombinant Sgt1, C-end truncated form, $10 \mu \mathrm{g} / \mathrm{ml}$ ) was adsorbed to the wells of 96-well plates (Nunc) in $0.1 \mathrm{M}$ carbonate buffer, $\mathrm{pH}$ 9.0 , overnight at $4^{\circ} \mathrm{C}$. The remaining adsorption sites were blocked with PBS, containing 0.1\% Tween-20 and $0.5 \%$ gelatine (PBS-T-Gel); antisera or specific antibodies in properly concentrations/dilutions were added in $0.1 \mathrm{ml}$ of PBS-T-Gel to each well; incubation with antibodies lasted $2 \mathrm{~h}$ at $37^{\circ} \mathrm{C}$. All further procedures were carried out at $37^{\circ} \mathrm{C}$. Then, wells were washed with PBS-T, and secondary antibodies of gout against whole molecules of rabbit IgG conjugated with horse-radish peroxidase (Promega) were added to the wells and incubated for $1 \mathrm{~h}$. After washing with PBS-T, the reaction product was visualized by adding ABTS $(0.5 \mathrm{mg} / \mathrm{ml}$, Sigma $)$ to $50 \mathrm{mM}$ sodium citrate buffer, $\mathrm{pH}$ 5.0 , and $0.05 \% \mathrm{H}_{2} \mathrm{O}_{2}$. The reaction was stopped by adding of $0.5 \mathrm{ml}$ citrate buffer containing $0.3 \% \mathrm{NaN}_{3}$, and the result of reaction was assayed quantitatively on BioLab ridder (UK).

Western-blot analysis. The specificity of anti-Sgt1 antibodies and their possible cross-reactivity was revealed using Western-blot analysis as described in [16] with some modifications.

After separation by electrophoresis polypeptides were electrotransferred onto nitrocellulose membrane (Protran, USA) in $20 \mathrm{mM}$ Tris/100 mM glycine/20\% methanol buffer at $200 \mathrm{~mA} / 20 \mathrm{~V}$ during $2 \mathrm{~h}$. Protein

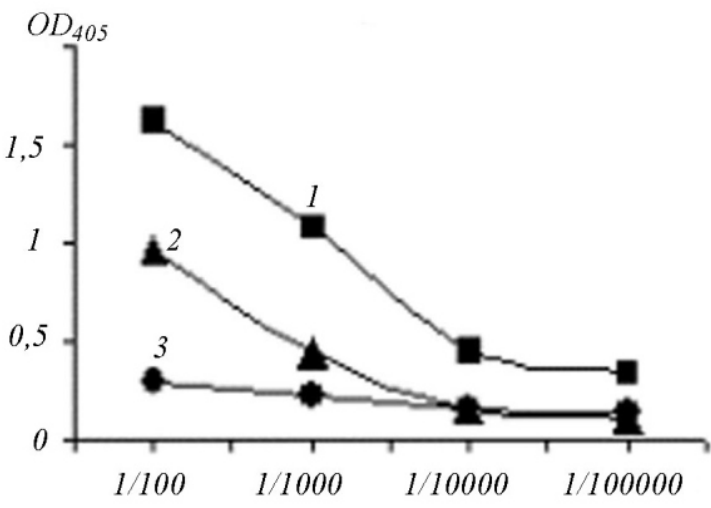

Fig.2 Immunoreactivity of specific anti-Sgt1 antiserum (2) and monospecific anti-Sgt1 antibodies (1), defined by immunosorbent essay (ELIZA); 3 - antiserum of intact (not-immunized rabbit)

transfer onto nitrocellulose membrane under pressure ("passive") was done overnight in PBS buffer. Washing and blockage of the membrane was done in PBS-T buffer $\left(80 \mathrm{mM} \mathrm{Na}_{2} \mathrm{HPO}_{4} ; 20 \mathrm{mM} \mathrm{NaH} \mathrm{PO}_{4} ; 100 \mathrm{mM}\right.$ $\mathrm{NaCL} \mathrm{pH} 7.5 ; 0.1 \%$ Tween-20) containing $5 \%$ of fatty-free dry milk (PBS-T-M) at room temperature. All further procedures including the incubation with specific antisera or purified antibodies were carried out in PBS-T-M buffer at room temperature. After washing with PBS-T, secondary antibodies of gout against whole molecules of rabbit IgG conjugated with horse-radish peroxidase (Promega) were added to the membrane and incubated during $2 \mathrm{~h}$. After extensive washing with PBS-T, the fluorogene ECL (Amersham, UK) was added to the membrane (according to the manufacturer's protocol) and exposed on the X-ray film (Kodak) for visualization of the signals.

Results and discussion. The study of apoptotic signaling regulation revealed the important role of molecular chaperons Hsp90 family in the mechanisms of activation and suppression of such signal pathways [17, 18]. It has been shown recently that the Hsp90 is one of the major factors in the mechanism of quality control of proteins via poly-ubiquitination and proteasome substrate degradation [19]. Investigation of Hsp90 structure revealed the $\mathrm{C}$-terminal domain of dimerization and ATPase N-terminal domain, which interact with different substrates and numerous cohort co-chaperons [20]. The sequencing of recently discovered protein Sgt1 [6], participating in anti-microbial innate immu- 


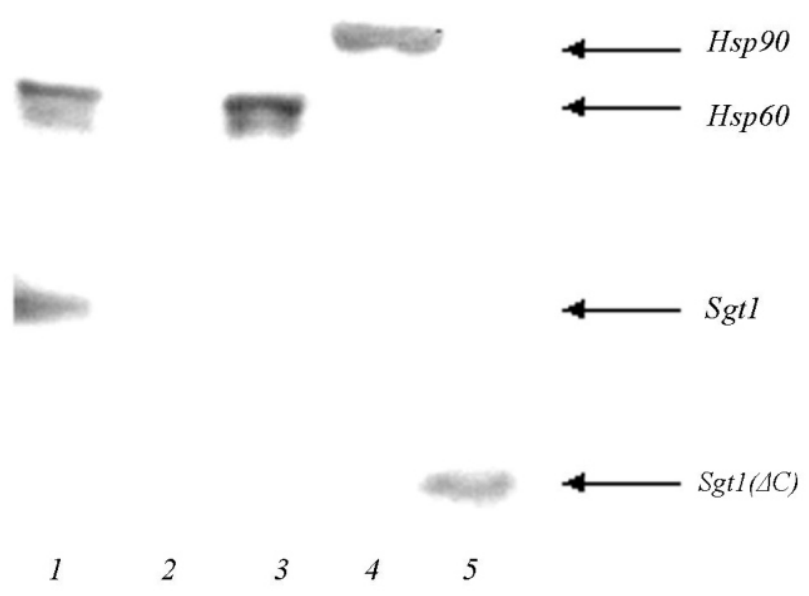

Fig. 3 Immune cross-reactivity of monospecific anti-Sgt1 antibodies, defined by Western blot analysis: 1 - extract of cytoplasmic fraction of mouse myocardium; 2 - bovine serum albumin; 3 - recombinant GroEL (prokaryotic homologue of eukaryotic Hsp60); 4 - Hsp90, isolated from the bovine brain; 5 - recombinant Sgt1 $(\Delta \mathrm{C}$ fragment)

nity, identified that both plant and mammalian Sgt1 protein are composed of 3 domains. Sgtl central CS-domain was identified as Hsp90-linked protein p23-like structure [7, 8] capable of interacting with Hsp90 [21]. C-terminal domain of Sgt1 molecule (SGS) interacts with $\mathrm{Ca}^{2+}$-binding S100 proteins [22], such as annexins, psoriasin, calcyclin, parvalbumin, calmodulin, and troponins which may suggest the important role of Sgt1 in contractility of muscle cells, and cardiomyocytes in particular [23].

The investigation of abovementioned problems depends on the availability of specific anti-Sgt1 antibodies with high affinity. The development of such antibodies is complicated due to high evolutionary conservative structure and low immunogenicity of Sgt1 molecule. Thus, the first stage of such antibodies generation was the development of specific scheme of animals (rabbit) immunization. We used the C-terminal fragment (molecular weight $\sim 20 \mathrm{kDa}$ ) of recombinant human Sgt1 with 95\% of purity (Fig.1). We obtained anti-Sgt1 immune sera with sufficient titer (more than $10^{-4}$ ) only after 5 immunization steps although we used only $300 \mu \mathrm{g}$ of antigen in all procedures using unique scheme of immunization, previously developed in our laboratory.
After all the procedures of antibodies purification, their affinity, specificity and possible cross-reactivity were identified. The results of identification of the titer of specific anti-Sgt1 antisera and anti-Sgt antibodies at different purification steps on the different matrixes are presented in Fig.2. The affinity of the specific antibodies obtained increased with every step of purification.

The problem of the development of specific antibodies directed against recombinant antigens is complicated by the fact that the antibodies obtained de novo are very often capable of recognizing the recombinant antigen only, but not the native one (in animal cells and tissue lysates), even at detected expression of gene for protein investigated. The mechanism of such process is not known but could be linked with differences in recombinant and native proteins folding. Therefore, the characterization of new antibodies specificity and cross-reactivity by Western-blot analysis is important. The results presented in Fig. 3 demonstrate specific interaction of anti-Sgt1 antibodies with recombinant antigen as well as corresponding polypeptide with molecular weight $\sim 40 \mathrm{kDa}$ in lysates of mouse cardiomyocytes. Moreover, anti-Sgt1 antibodies obtained recognized native Hsp90 purified from bovine brain, recombinant GroEL (prokaryotic analog of eukaryotic Hsp60) [24], and native Hsp60 in mouse cardiomyocytes lysate. We supposed that Sgt1 has a common domain(s) with Hsp60 supported by anti-Sgt1 cross-reactivity in Western-blot analysis. In this case our further investigations should be concentrated on common domains searching with sequencing of such domains, and evaluation of possible Sgtl acting like co-chaperon or target protein. This is sufficient to understand the role of Sgtg1 and other CHORD-containing proteins in cardiomyocytes functioning and anti-stress response, whose disregulation is manifested in cardiovascular pathologies progression.

Conclusions. Anti-Sgt1 monospecific polyclonal antibodies with high purity and affinity have been first developed. Anti-Sgt1 obtained can be used in ELISA, Western-blot analysis and immunoprecipitation.

We observed the cross-reactivity of anti-Sgt1 antibodies with chaperons Hsp90 and Hsp60 for the first time. 
Л. Н. Капустян, О. Т. Рожко, В. И. Бобык, И. В. Крупская, Л. Л. Сидорик

Получение и характеристика анти-sgt1 моноспецифических антител

Резюме

Описан метод получения и очистки, а также охарактеризованы свойства моноспецифических поликлональных антител против высококонсервативного эукариотного белка Sgt1, играющего важную роль в регуляции клеточного ичикла, в Hsp90-опосредованной протеасомной деградаџии белков $и$ вместе с другими молекулярными шаперонами и ко-шаперонами являющегося важным регулятором про- и антиапоптических сигнальных путей. Изучение роли и функичй Sgt1 в комплексах с белками шаперонового семейства Нsp90 необходимо для понимания механизмов регуляиии сигнальных процессов, контролирующих жизнь и смерть клетки, что критично для развития сердечно-сосудистых патологий, в частности, дилятационной кардиомиопатии.

Ключевые слова: моноспечифические антитела, Sgt1, шапероны.

Л. М. Капустян, О. Т. Рожко, В. І. Бобик, І. В. Крупська, Л. Л. Сидорик

Одержання та характеристика анти-Sgt1 моноспецифічних антитіл

Резюме

Описано метод одержання і очищення та охарактеризовано властивості моноспецифічних поліклональних антитіл проти висококонсервативного еукаріотного білка Sgt1, який $\epsilon$ важливим чинником регуляиії клітинного ииклу, бере участь у Hsp90-опосередкованій протеасомній деградації білків і разом з іншими шаперонами і кошаперонами відіграє важливу роль у регуляиії про- та антиапоптичних сигнальних шляхів. Вивчення ролі $i$ функиій Sgt1 y комплексах з білками шаперонової родини Нsp90 необхідно для розуміння механізмів регуляиії сигнальних процесів, які контролюють життя та смерть клітини, що є критичним у розвитку багатьох сериево-судинних патологій, зокрема, дилятаційноӥ кардіоміопатії.

Ключові слова: моноспечифічні антитіла, Sgt1, шаперони.

\section{REFERENCES}

1. Kitagawa K., Skowyra D., Elledge S. J., Harper J. W., Hieter P. SGT1 encodes an essential component of the yeast kinetochore assembly pathway and a novel subunit of the SCF ubiquitin ligase complex // Mol. Cell.-1999.-4.P. 21-33.

2. Rodrigo-Brenni M. C., Thomas S., Bouck D. C., Kaplan K. $B$. Sgt1p and Skp1p modulate the assembly and turnover of CB3F complexes required for proper kinetochor function // Mol. Cell. Biol.-2003.-15.-P. 3366-3378.
3. Yamamoto T., Mori Y., Ishibashi T., Uchiyama Y., Sakaguchi N., Furukawa T., Hashimoto J., Sakaguchi K. Characterization of RAD6 from a higher plant, rice (Oriza sativa L.) and its interaction with Sgt1, a subunit of the SCF ubiquitin ligase complex // Biochem. and Biophys. Res. Communs.-2004.-314.-P. 434-439.

4. Gray W. M., Muskett P. R., Chuang H. W., Parker J. E. Arabidopsis SGT1b is required for SCF(TIFR1)-mediated auxin response // Plant Cell.-2003.-15.-P. 1310-1319.

5. Spiechowicz M., Filipek $A$. The expression and function of Sgt1 protein in eukaryotic cells // Acta Neurobiol. Exp.-2005.-65.-P. 161-165.

6. Zou X., Ji C., Wang L., Wu M., Zheng H., Xu J., Jin F., Gu S., Ying K., Xie Y., Mao Y. Molecular cloning and characterization of SGT1.2, a novel splice variant of Homo sapiens SGT1// DNA Sequencing.-2004.-15.-P. 140-143.

7. Filipek A., Kuznicki J. Molecular cloning and expression of a mouse braine cDNA encoding a novel protein target of calcyclin // J. Neurochem.-1998.-70.-P. 1793-1798.

8. Matsuzawa S., Reed J. Siah-1, SIP, and Ebi collaborate in a novel pathway for beta-catenin degradation linked to $\mathrm{p} 53$ response // Mol. Cell.-2001.-7.-P. 915-926.

9. Никандров В. Н., Чаплинская Е. В. Протеин S-100: структурно-функциональные свойства и роль в нервной ткани // Біополімери і клітина.-2005.-21, № 1.-С. 12-22.

10. Lee Y.-T., JacobJ., Michowski W., Nowotny M., Kuznicki J., Chazin $W$. J. Human Sgt1 binds HSP90 through the CHORD-Sgt1 domain and not tetratricopeptide repeat domain // J. Biol. Chem.-2004.-279.-P. 16511-16517.

11. Sidorik L., Rybkinska T., Bakhiya N., Rodnin N., Filonenko V., Entelis N., Martin R., Tarassov I., Matsuka G. Kh. The immunochemical cross-reactivity between cytoplasmic and mitochondrial mammalian lysyl-tRNA synthetases // Биополимеры и клетка.-2000.-16.-P. 363-368.

12. Laemmli $U$. K. Cleavage of structural proteins during the assembly of bacteriophage T4 // Nature.-1970.-227.P. 680-685.

13. Bradford $M$. A rapid and sensitive method for quantitation of microgram quantities of protein utilizing the principle of protein binding // Anal. Biochem.-1976.-46.-P. 193-200.

14. Sidorik L. L., Gudzera O. L., Dragovoz V. A., Tukalo M. A., Beresten $S$. F. Immunochemical non-cross-reactivity between eukaryotic and prokaryotic seryl-tRNA synthetases // FEBS Lett.-1991.-292.-P. 76-78.

15. Matsiota P., Dosquet P., Guilbert B., Avrameas $S$. Natural autoantibodies in systemic lupus erythematosus // Clin. Exp. Immunol.-1987.-69.-P. 79-88.

16. Ternynck T., Bleux C., Gregoige J., Avrameas S., Kanellopoulos-Langevin C. Comparison between autoantibodies arising during Trypanosoma cruzi infection in mice and natural autoantibodies // J. Immunol.-1990.-144.- P. 1504-1511.

17. Dispersin G. D., Borgers M. Apoptosis in the heart: About programmed cell death and survival // News Physiol.-2001.-16.-P. 41-46.

18. Gobbesman S., Wockner S., Maurizi M. Protein quality control: triage by chaperones and proteases // Genes and Develop.-1997.-11.-P. 815-823.

19. Welchman R. L., Gordon C., Mayer R. J. Ubiquitin and ubiquitin-like proteins as multifunctional signals // Nat. Rew.-2005.-6.-P. 599-609.

20. Jakob U. HSP90 - news from the front // Frontiers Biosci.-1996.-1.-P. d309-317. 
21. Nowotny M., Spiechowicz M., Jastrgebska B., Filipek A., Kitagawa K., Kuznicki J. Calcium-regulated interaction of Sgt1 with S100A6 (Calcyclin) and other S100 proteins // J. Biol. Chem.-2003.-78.-P. 26923-26928.

22. Snoeckx L. H. E. H., Cornelussen R. N., VanNieuwenhoven F. A., Reneman F. A., Reneman R. S., VanDerVusse G. J. Heat shock proteins and cardiovascular pathophysiology // Physiol. Rew.-2001.-81.-P. 1461-1497.
23. Капустян Л. Н., Киямова Р. Г., Гришкова В. С., Терентьев А. Г., Филоненко В. В., Сидорик Л. Л. Получение рекомбинантного шаперона GroEL и его иммунологическая кросс-реактивность с Hsp60 // Біополімери і клітина.-2006.-22, № 2.-С. 117-120.

UDC 577.21

Received 31.08.07 